\title{
Energy budget and ecological role of mangrove epibenthos in the Caeté estuary, North Brazil
}

\author{
Volker Koch $^{1, *}$, Matthias Wolff ${ }^{2}$ \\ ${ }^{1}$ Center for Coastal Studies, Ap. Postal 15, 23740 Puerto San Carlos, Baja California Sur, Mexico \\ ${ }^{2}$ Center for Tropical Marine Ecology, Fahrenheitstraße 6, 28359 Bremen, Germany
}

\begin{abstract}
Epibenthic community structure, somatic production and energy flow were studied in the Caeté mangrove estuary in North Brazil on for 3 representative strata: high intertidal forest $(F)$, small creeks in the forest (SC) and open mudbanks of large intertidal creeks (LC). Seven decapod crustaceans and 1 gastropod accounted for $>95 \%$ of total epifaunal biomass, with highest values in the forest followed by large and small creeks (228.2, 103.6 and $69.7 \mathrm{~kJ} \mathrm{~m}^{-2}$ respectively). The leafconsuming crab Ucides cordatus was clearly dominant in the forest, followed by the fiddler crabs $U_{C a}$ rapax and $U$. vocator. The large creek stratum was strongly dominated by the fiddler crab U. maracoani, while in the small creek 4 species (Uca cumulanta, U. maracoani, Pachygrapsus gracilis and Eurytium limosum) contributed similar quantities to total biomass. Per area somatic production $(P)$ and respiration $(R)$ was highest in the large creek, followed by the forest and small creek stratum. Based on the contribution of each stratum, total biomass $\left(332.8 \mathrm{~kJ} \mathrm{~m}^{-2}\right)$, production $\left(455.8 \mathrm{~kJ} \mathrm{~m}^{-2} \mathrm{yr}^{-1}\right)$ and assimilation (2959.6 $\mathrm{kJ} \mathrm{m}^{-2} \mathrm{yr}^{-1}$ ) were estimated for the whole area. While the herbivorous feeding guild with $U$. cordatus was the most prominent in terms of biomass ( $75 \%$ of the total), the detritivorous fiddler crabs and $P$. gracilis clearly dominated in terms of respiration and somatic production (60 and $90 \%$ respectively). Carnivores (Eurytium limosum and Thais coronata) contributed $<2 \%$ to the epibenthic energy budget. A system picture emerges whereby energy flow is strongly dominated by herbivorous and detritivorous species. Both guilds probably promote mangrove primary production by (1) conserving nutrients in the system, (2) enhancing nutrient remineralization, and (3) oxygenizing the soil through their burrowing and feeding activities. A resulting positive feedback loop between mangroves, crabs and bacteria could explain the very high mangrove productivity and the high efficiency with which mangrove primary production is assimilated by the crabs (almost 15\%).
\end{abstract}

KEY WORDS: Mangrove benthos $\cdot$ Energy flow $\cdot$ Production $\cdot$ Assimilation $\cdot$ Energy budget $\cdot$ Fiddler crabs $\cdot U_{c a} \cdot U_{c i d e s}$

- Resale or republication not permitted without written consent of the publisher

\section{INTRODUCTION}

The intertidal benthos in mangrove ecosystems is (besides the mangrove trees themselves) the main contributor to the overall system biomass, with up to 45 to $70 \%$ of total faunal biomass and most energy cycling seems to occur within the benthic domain (Büttner 1997, Wolff et al. 1998, 2000, Koch 1999). The

\footnotetext{
*E-mail: vokoch@gmx.net
}

most important feeding guilds are not only depositfeeders (e.g. fiddler crabs), herbivores (e.g. leaf-eating land crabs) and filter-feeders (e.g. bivalve molluscs and balanid crustaceans), but also predators such as snails and carnivorous crabs (e.g. Gerlach 1958, Macnae 1968, Jones 1984, Alongi \& Sasekumar 1992, Koch 1995, 1999, Buettner 1997). The available data on zonation and species distribution suggest that high intertidal mangrove forests (such as the system under study) are often dominated by decapod crustaceans while the faunal composition in low intertidal man- 
groves is shifted towards encrusting filter-feeders such as mangrove oysters and barnacles.

Herbivory and detritivory appear to be the dominant feeding modes which can be expected, as mangrove leaves are the major input source of organic matter (Odum \& Heald 1972, Dye \& Lasiak 1987, Lee 1989, Robertson \& Daniel 1989, Robertson 1991, Robertson et al. 1992). Removal of mangrove leaves by leaf-eating crabs through consumption or burial can range between 28 and $79 \%$ of annual leaf-litter fall in low and high intertidal mangroves respectively, thus considerably lowering export of organic material to coastal waters (Robertson \& Daniel 1989, Robertson 1986, 1991). By shredding and mastication of the leaves, crabs provide bacteria with large amounts of suitable substrate which can be degraded much faster than whole mangrove leaves. Leaf degradation (and thus nutrient remineralization) can be enhanced by almost 2 orders of magnitude when leaf-consuming crabs are involved (Robertson \& Daniel 1989, Robertson et al. 1992). The high bacterial production in mangroves (Alongi 1988) forms a rich food source for depositfeeding species which mainly assimilate the bacterial biomass from the ingested organic material (plant detritus) (Montague 1980, Robertson \& Newell 1982, Genoni 1985, Dye \& Lasiak 1987). Studies in North American saltmarshes and other wetlands have demonstrated the importance of this trophic guild (consisting mainly of fiddler crabs) as a major food source for many predators (e.g. Teal 1962, Montague 1980).

While a general picture of the importance of mangrove benthos has emerged over the last years, only limited quantitative work has been done. Very little is known as yet about secondary production and the total energy requirements of mangrove epibenthos, the contribution of different trophic guilds to system energy flow or the proportion of mangrove primary production used and actually assimilated by this faunal group. The studies of Macintosh $(1977,1984)$ in Malaysian mangroves comprise the only work known to the authors in which secondary production of intertidal epibenthos has been estimated with values ranging from 11 to $459 \mathrm{~kJ} \mathrm{~m}^{-2} \mathrm{yr}^{-1}$ for several mangrove crabs, mainly deposit-feeding species. Total assimilation is unknown to date, despite strong indications that this faunal group can be a major contributor to the total energy flow in mangrove ecosystems.

The present study was undertaken in the Caeté estuary near Braganca (Pará, North Brazil) which forms part of one of the largest mangrove areas worldwide (Spalding et al. 1997). The most important resource in the system is the edible mangrove crab Ucides cordatus, with an annual catch of approx. $1500 \mathrm{t}$ (Wolff et al. 2000 ). Over $40 \%$ of the rural population in the area depends on this species as their main income source
(Glaser et al. 1997). Agriculture, fishing and (illegal) logging of mangrove wood for charcoal production and construction of houses and fish traps are further important economic activities.

In the research presented here, we aimed at quantifying biomass, somatic production and total assimilation of the epibenthic assemblage in different mangrove habitats in order to determine the magnitude of energy flow through this group and to evaluate its ecological role within the mangrove ecosystem. Specifically we adressed the folowing research questions: (1) What are the dominant species in terms of biomass and abundance and how does species composition differ among habitats? (2) How are biomass, production and assimilation distributed among different species and trophic guilds, and what part of mangrove primary production is being used? (3) What is the functional role of intertidal epibenthos in the system, and how do the dominant benthic species influence processes at the ecosystem scale?

\section{MATERIALS AND METHODS}

Study area. The study area is located about $200 \mathrm{~km}$ east of Belém on a peninsula in the estuary of the Caeté river (Fig. 1a,b) with a mangrove cover of about $110 \mathrm{~km}^{2}$. The tidal regime in the estuary is semidiurnal, with a range of 3 to $5 \mathrm{~m}$. Because of its high elevation, most of the forest is inundated only around spring-tide, while numerous channels and creeks running through the forest are flooded daily. Three species of mangroves occur: Rhizophora mangle (L.) (Rhizophoraceae), Avicennia germinans (L.) (Avicenniaceae) and Laguncularia racemosa (L.) (Combretaceae). $R$. mangle is dominant in most parts of the peninsula, followed by A. germinans. L. racemosa mainly grows in disturbed sites on the banks of tidal channels and near the road (Thüllen 1997, Mehlig pers. comm).

The region receives about $2500 \mathrm{~mm}$ of rainfall $\mathrm{yr}^{-1}$ (INMET 1992) mostly between January and June (Fig. 2). Salinity shows corresponding oscillations, with peak values of up to 39 PSU at the end of the dry season, dropping to less than 15 PSU in the rainy season. In 1998 and 1999, even lower values were recorded due to higher precipitation (MADAM [Mangrove Dynamics and Management] project unpubl. data). Air temperature varies little throughout the year $\left(25\right.$ to $\left.28^{\circ} \mathrm{C}\right)$, with lowest values occurring in the rainy season after heavy rainfalls; water temperatures range between 27 and $30^{\circ} \mathrm{C}$. The study site was located at the Furo do Meio, a large creek in the central part of the peninsula (Fig. 1b), as this area was considered representative of a large part of the study 


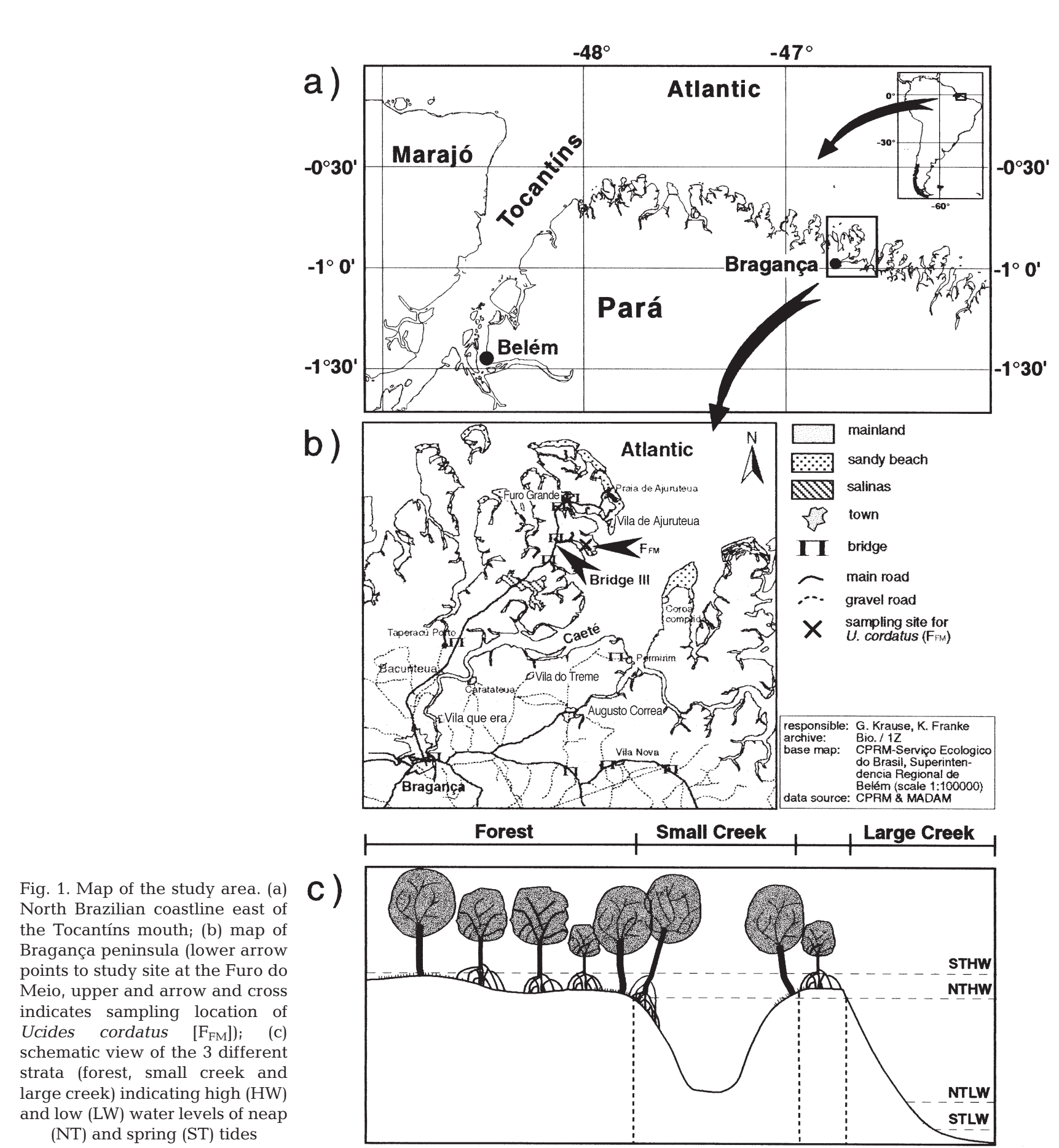

area. It is characterized by a mixed Rhizophora mangle/Avicennia germinans forest, with a few L. racemosa trees. The forest floor remains dry for 8 to $10 \mathrm{~d}$ between spring tides.

Field sampling. As preliminary sampling had revealed great faunal differences between the high intertidal forest $(\mathrm{F})$, small creeks running through the forest (SC) and the unshaded mudbanks of large creeks (LC), the study site was divided into these respective strata (Fig. 1c). Mangrove crabs (except for the largest species, Ucides cordatus) were sampled with enclosure quadrats of $0.49 \mathrm{~m}^{2}$, using 8 randomly allocated replicates in the small and large creek strata. The forest stratum was further subdivided according to the relative cover of particular vegetation types (Thüllen 1997, Mehlig pers. comm.): Rhizophora mangle (4 quadrats), Avicennia germinans (2 quadrats), mixed R. mangle/A. germinans (1 quadrat), and clearings (1 quadrat). Within each substratum, the quadrats were allocated at random. Four $70 \times 20 \mathrm{~cm}$ acrylic glass 


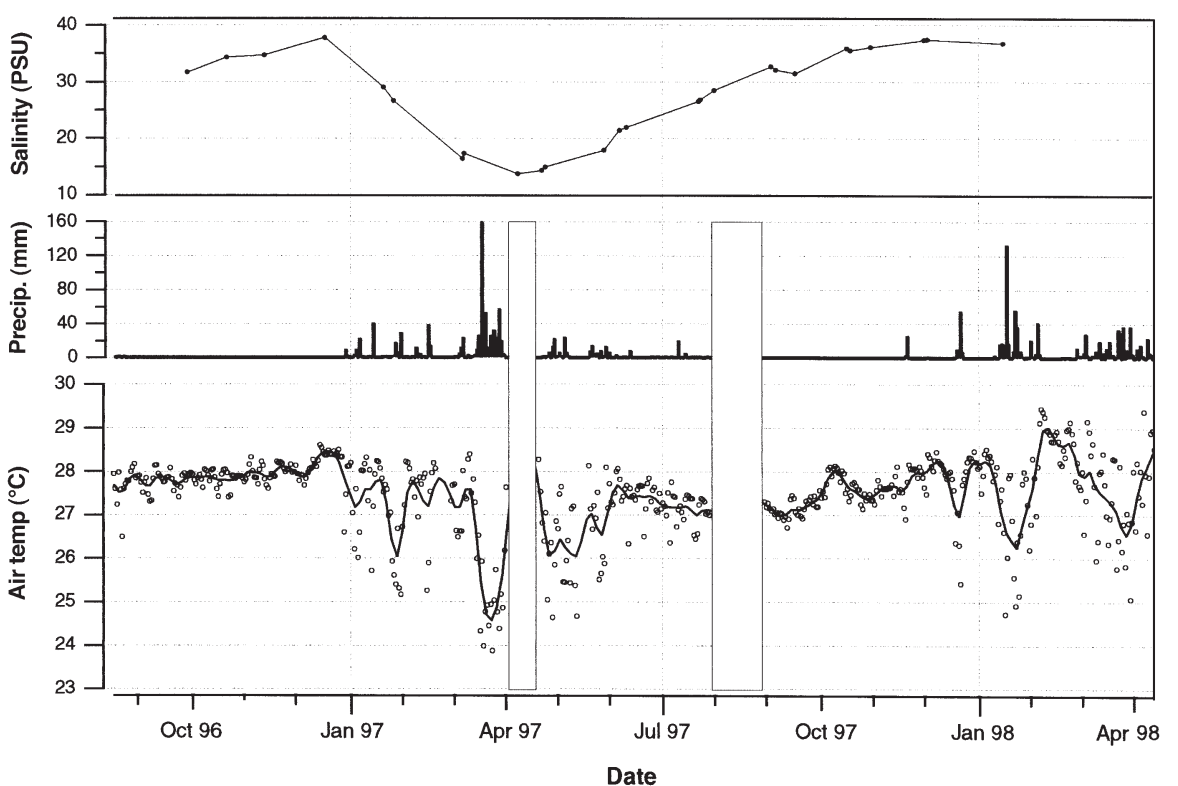

Fig. 2. Air temperature, precipitation (daily averages) and salinity (points indicate sampling dates) recorded at Furo do Meio with an automatic meteorological station. Blank vertical bars indicate periods when no data was available plates were fitted together to form individual sampling squares (solid frames could not be used because of the mangrove roots). The plates extended 3 to $5 \mathrm{~cm}$ into the sediment to prevent crabs from escaping. Quadrats were set up during early morning spring high tides while the burrows were covered with water. Since the crabs retreat to their burrows during inundation, this ensured that only animals inhabiting the sampled area were taken. Sampling in all strata began after the water had receded from the area; all replicates were visited 2 to 3 times to remove all specimens. Sediment disturbance, probing and digging was increased on subsequent visits as the crabs were found to readily leave their burrows when disturbed in this manner. Biomass removal efficiencies were estimated as $98 \%$ in the forest and small creek and $88 \%$ in the large creek (Koch 1999). All specimens were identified, sexed, measured to the nearest $0.1 \mathrm{~mm}$ and checked for molt status under a dissection microscope with a measuring eyepiece. Wet mass was determined to the nearest $0.01 \mathrm{~g}$.

The large mangrove crab Ucides cordatus was sampled with 8 replicates at bimonthly intervals at the mouth of the Furo do Meio (Fig. 1b) using larger quadrats $\left(25 \mathrm{~m}^{2}\right)$ because of its large size and low density. Two parallel transects were sampled perpendicular to a small elevated area in the forest. Distance between quadrats was random. Sampling (hand collection) was undertaken with the help of a professional crab collector. Each quadrat was delimited with a thin rope, and burrows that were exactly on the border were sampled only on 2 of the 4 sides. The crab collector probed every inhabited burrow and announced whether he had caught the crab or not to correct the catch for sampling efficiency. On most sampling occasions 60 to $80 \%$ of the specimens in a given quadrat were removed. In the laboratory, crabs were sexed, measured with a caliper rule to the nearest millimeter, weighed to the nearest $0.1 \mathrm{~g}$, and molt status checked. On the following day they were taken back alive to the mangrove.

The thaidid snail Thais coronata was locally abundant on mangrove logs in the low and mid intertidal. Two sites were sampled, one in a small shaded creek in the forest, the second on the unshaded mudbanks of a large creek. At each site, an isolated group of mangrove trunks was chosen from which all specimens were removed at bimonthly intervals, measured to the nearest $0.5 \mathrm{~mm}$ with a measuring box (Koch et al. 1998), and released at the sampling sites. In addition, in areas of 800 and $2400 \mathrm{~m}^{2}$ respectively, the total surface area of mangrove trunks in the intertidal area of the small and large creeks was determined to obtain biomass per area estimates (Koch 1999).

Energy budgets. Biomass determination: Size-mass relationships for ash-free dry mass (AFDM) were calculated for each of the 8 dominant species. Specimens were measured to the nearest $0.1 \mathrm{~mm}$ (carapax width of the crab species; shell height of the snail), dried at $95^{\circ} \mathrm{C}$ to a constant mass (entire crabs; soft parts and operculi of the snail), weighed to the nearest $0.1 \mathrm{mg}$ and ashed for $6 \mathrm{~h}$ at $540^{\circ} \mathrm{C}$ in a muffle furnace. Finally, the ash was weighed and AFDM was calculated. The AFDM of specimens caught during field sampling was then calculated from the respective size-mass relationship given by Koch (1999).

Somatic production: Estimates of somatic production of the dominant species were obtained using the following methods: 
(1) For the fiddler crabs, Ucides cordatus, Pachygrapsus gracilis and Thais coronata, the increment summation method (ISM) for somatic production $(P)$ of populations with recruitment and indistinguishable age classes was used (Crisp 1984):

$$
P=\sum_{s=1}^{s=m} \sum_{i=0}^{i=n} f_{i} \times G_{i} \times w_{i} \times t
$$

where $s=$ the sampling occasions from 1 to $\mathrm{m}, i=$ the size classes from 0 to $\mathrm{n}, G_{i}=$ the mass specific growth rate (taken from Koch 1999) of size class $i$ with mean mass $w_{i}$ and $f_{i}=$ the mean number of specimens in that size class during time interval $\Delta t$. (2) For Eurytium limosum the size-frequency method (Hynes \& Coleman 1968, Hamilton 1969) was used as modified by Benke (1979), since growth rates were not available for this species:

$$
P=\left[N \times \sum_{i=1}^{i=n}\left(f_{i}-f_{i+1}\right) \times\left(w_{i}-w_{i+1}\right)^{0.5}\right] \times 1 / \mathrm{CPI}
$$

where $N=$ the number of size classes, $f=$ the mean number of specimens in size class $i$ with mean mass $W_{i}$ and $\mathrm{CPI}=$ the cohort production interval, i.e. time taken to attain the largest size class. No data on the life span of Eurytium limosum were available to the author, therefore a value (2.3 yr) for the closely related xanthid crab Panopeus herbsti (McDonald 1982) was taken as an estimate. A size interval of $2 \mathrm{~mm}$ was chosen, yielding a total of 18 size classes.

Biomass turnover ratios $(P / B)$, obtained by the ISM method, were compared to the total mortality rates $(Z)$, calculated from lengthconverted catch curves (Koch 1999) for the 4 fiddler crabs and for Pachygrapsus gracilis. Allen (1971) demonstrated that both ratios are equal under steady state conditions and for the growth and mortality functions used herein (von Bertalanffy growth and single exponential mortality).

Assimilation: Annual respiration values for the field populations were taken from Koch (1999), who determined oxygen consumption of each of the 8 dominant species over its entire size range (between 60 and 100 individuals per species) and over the temperature range in the field. From these data, multiple regressions were calculated (temperature and mass as independent variables, $\mathrm{O}_{2}$ consumption as the dependent variable) which were then used to estimate the respiration of the field populations. Seasonal changes were not taken into account (for further details see Koch 1999). Biomass $(B)$, production $(P)$ and respiration $(R)$ were converted to energy equivalents by the following conversion factors (Crisp 1984): $1 \mathrm{~g}$ AFDM $=20.09 \mathrm{~kJ} ; 1 \mathrm{~g} \mathrm{O}_{2}=14.06 \mathrm{~kJ}$. Total assimilation (A) together with the energy budget were then calculated as $A=P+R$.

Net production efficiencies (NPE) were calculated as the percentage of assimilated energy allocated to production (i.e. P/A) (Caddy \& Sharp 1986), which is equal to the net growth efficiency $\left(K_{2}\right)$ of Ivlev (1966). To integrate biomass, production and assimilation estimates from the different strata for the whole area around the Furo do Meio, the following assumption was made, based on their relative contributions: forest was assumed to represent $75 \%$, small creeks $17 \%$, and mudbanks of large creeks $8 \%$ of the intertidal area.

\section{RESULTS}

\section{Biomass and abundance}

Twentyfive epibenthic species were found, with the highest numbers in small creek areas (17), followed by large creek (15) and forest (13) areas (Table 1).

Table 1. Species (x) encountered during the sampling period. $\mathrm{F}, \mathrm{SC}$, and

\begin{tabular}{|c|c|c|c|c|}
\hline $\begin{array}{l}\text { Order } \\
\text { Family }\end{array}$ & Species & $\mathrm{F}$ & $\mathrm{SC}$ & LC \\
\hline \multicolumn{5}{|l|}{ Decapoda } \\
\hline Alpheidae & Alpheus sp. & & $\mathrm{x}$ & $\mathrm{x}$ \\
\hline Diogenidae & Clibanarius vittatus & & $\mathrm{x}$ & $\mathrm{x}$ \\
\hline \multirow[t]{6}{*}{ Grapsidae } & Aratus pisoni & $\mathrm{x}$ & $\mathrm{x}$ & \\
\hline & Goniopsis cruentata & $\mathrm{x}$ & $\mathrm{x}$ & $\mathrm{x}$ \\
\hline & Metasesarma rubripes & $\mathrm{x}$ & & \\
\hline & Pachygrapsus gracilis & & $\mathrm{x}$ & $\mathrm{x}$ \\
\hline & Searma curacoense & $\mathrm{x}$ & $\mathrm{x}$ & \\
\hline & Sesarma rectum & $\mathrm{x}$ & & \\
\hline \multirow[t]{6}{*}{ Ocypodidae } & Uca cumulanta & $\mathrm{x}$ & $\mathrm{x}$ & $\mathrm{x}$ \\
\hline & Uca maracoani & & $\mathrm{x}$ & $\mathrm{x}$ \\
\hline & Uca rapax & $\mathrm{x}$ & & \\
\hline & Uca thayeri & $\mathrm{x}$ & $\mathrm{x}$ & \\
\hline & Uca vocator & $\mathrm{x}$ & & \\
\hline & Ucides cordatus & $\mathrm{x}$ & $\mathrm{x}$ & \\
\hline Porcellanidae & Petrolisthes armatus & & $\mathrm{x}$ & $\mathrm{x}$ \\
\hline \multirow{2}{*}{ Portunidae } & Callinectes bocourti & & $\mathrm{x}$ & $\mathrm{x}$ \\
\hline & Callinectes exasperatus & & $\mathrm{x}$ & $\mathrm{x}$ \\
\hline \multirow[t]{3}{*}{ Xanthidae } & Eurytium limosum & $\mathrm{x}$ & $\mathrm{x}$ & $\mathrm{x}$ \\
\hline & Menippe nodifrons & & & $\mathrm{x}$ \\
\hline & Panopeus lacustris & & $\mathrm{x}$ & $\mathrm{x}$ \\
\hline \multicolumn{5}{|l|}{ Stomatopoda } \\
\hline Squillidae & Squilla sp. & & & $\mathrm{x}$ \\
\hline \multicolumn{5}{|l|}{ Gastropoda } \\
\hline \multicolumn{5}{|l|}{ Mesogastropoda } \\
\hline Littorinidae & Littorina scabra angulifera & $\mathrm{x}$ & & \\
\hline \multicolumn{5}{|l|}{ Neogastropoda } \\
\hline Thaididae & Thais coronata coronata & & $\mathrm{x}$ & $\mathrm{x}$ \\
\hline & Thais haemastoma floridiana & & $\mathrm{x}$ & $\mathrm{x}$ \\
\hline \multicolumn{5}{|l|}{ Basommatophora } \\
\hline Melampidae & Melampus coffeus & $\mathrm{x}$ & & \\
\hline
\end{tabular}
LC: habitat types forest, small creek and large creek respectively 

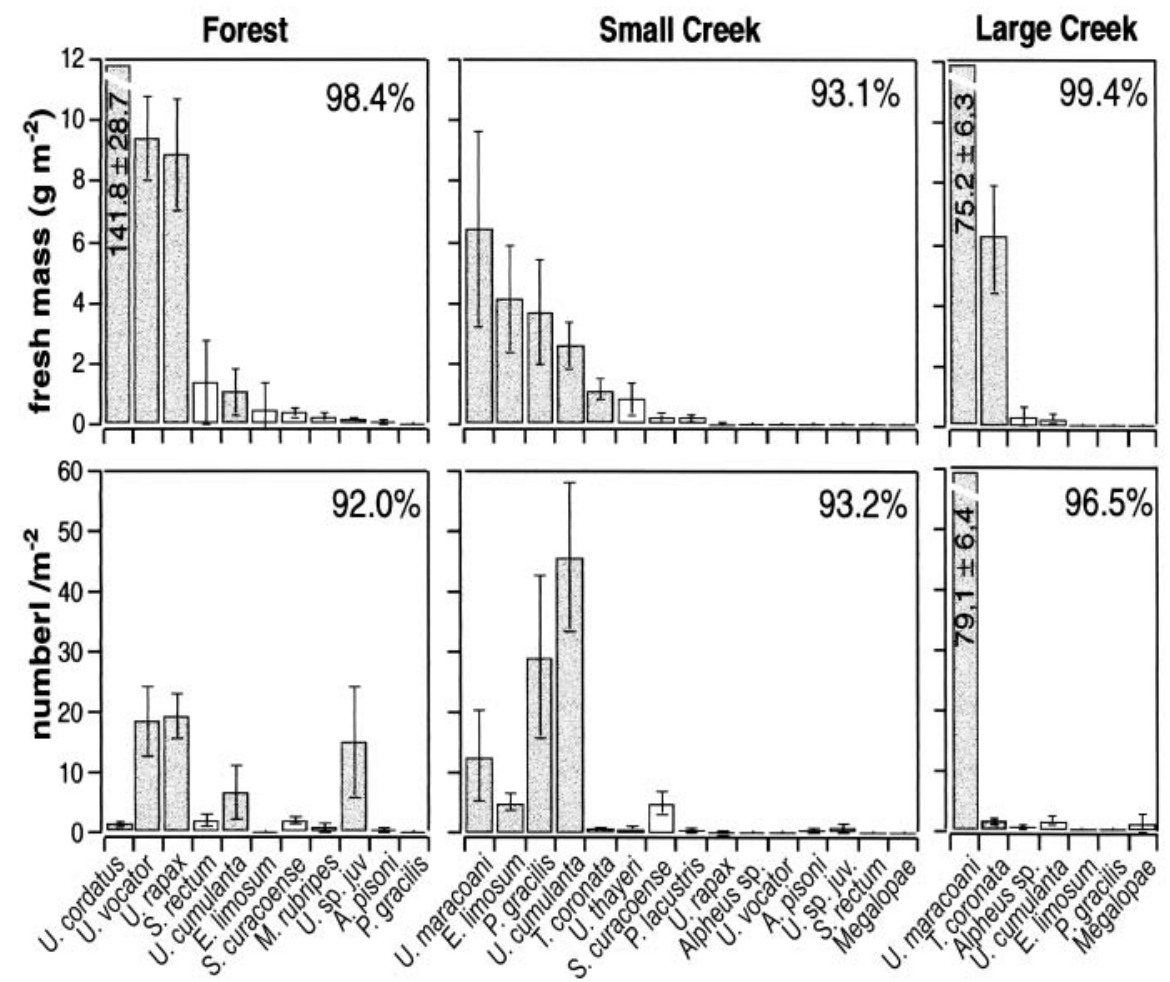

Fig. 3. Average $( \pm \mathrm{SE})$ biomass ( $g$ fresh mass $\mathrm{m}^{-2}$ ) and abundance (specimens $\mathrm{m}^{-2}$ ) of the species sampled in the forest, and in the small and large creeks. Species selected for production calculations are represented by grey bars, and their contribution to total biomass/abundance is given in the upper right corner of each graph. Full specific names in Table 1
The average biomass (fresh mass $\pm \mathrm{SE}$ ) and abundance $(n \pm S E)$ of all species collected in the 3 habitats are given in Fig. 3. Biomass was highest in the forest, followed by the large creek and small creek strata areas $\left(172.1,75.7\right.$ and $18.2 \mathrm{~g} \mathrm{~m}^{-2}$ respectively). In the forest, the leaf-eating Ucides cordatus was dominant in terms of biomass, followed by the fiddler crabs Uca rapax and $U$. vocator, which had the highest abundance in this stratum. In the small creek stratum, the fiddler crab U. maracoani contributed most to the total biomass, followed by the xanthid crab Eurytium limosum, the grapsid crab Pachygrapsus gracilis and another fiddler crab ( $U$. cumulanta). The latter 2 crabs were by far the most abundant species in this habitat. The large creek stratum was strongly dominated by $U$. maracoani. Contribution of the selected species to total epibenthic biomass was always over 90\%. Biomass dominance of individual species was highest in the large creek, followed by the forest and small creek strata.

\section{Energy budgets}

Table 2 summarizes the energy budgets of the species studied. In addition, $P / B$ and $R / B$ ratios and net production efficiencies (NPE) are given, as well as total mortality rates $(Z)$, where available (Koch 1999). Ucides cordatus contributed most to the biomass in the forest $(84 \%)$, while the fiddler crabs dominated in terms of production (87\%) and respiration (53\%). In the small creek, biomass was distributed more evenly. In terms of production, Uca cumulanta had the highest contribution here (42\%), followed by Uca maracoani (28\%), Pachygrapsus gracilis (22\%) and Eurytium limosum $(8 \%)$, while production of the snail Thais coronata was negligible. Production in the large creek was more than double that in the other strata, with $U$. maracoani accounting for over $95 \%$ of biomass, production and respiration. Here, T. coronata had a much higher production than the small creek. An energy budget for the whole area is given in the last row of Table 2. Overall assemblage $P / B$ was 1.37 , with $U$ cides cordatus having clearly the largest influence ( $P / B$ without this species $=5.27$ ).

The contribution of the different trophic guilds to total biomass, and assimilation production is shown in Table 3 for all strata combined. Ucides cordatus was dominant in terms of biomass $(B)$, while the deposit feeders (all fiddler crabs and Pachygrapsus gracilis) contributed almost $90 \%$ to total prodction $(P)$ and over $65 \%$ to total assimilation $(A)$. Predators (Eurytium limosum and Thais coronata) contributed very little to total $B, P$ and $A(<2 \%)$. In terms of total assimilation, the deposit feeders were clearly the most important group, followed by the herbivorous U. cordatus, while carnivores were of minor importance in the epibenthic assemblage. Fiddler crabs clearly dominated (>95\%) $B, P$ and $A$ of the deposit-feeding guild. 
Table 2. Summary of energy-flow calculations. Assimilation: sum of production and respiration; $P / B$ : production/biomass ratio; $Z$ : instantaneous mortality rates (from Koch 1999); $R / B$ : respiration/biomass ratio; NPE: net production efficiency (i.e. production/assimilation ratio). Percentages after habitat names: proportional sizes used for calculation of total energy flow in the area around the Furo do Meio (last row: 'Total'). nd: no data

\begin{tabular}{|c|c|c|c|c|c|c|c|c|}
\hline $\begin{array}{l}\text { Habitat } \\
\text { Species }\end{array}$ & $\begin{array}{l}\text { Biomass } \\
\left(\mathrm{kJ} \mathrm{m}^{-2}\right)\end{array}$ & Production & $\begin{array}{l}\text { Respiration } \\
-\left(\mathrm{kJ} \mathrm{m}^{-2} \mathrm{yr}^{-1}\right)\end{array}$ & Assimilation & $P / B$ & $\underset{\left(\mathrm{yr}^{-1}\right)}{Z}$ & $R / B$ & $\begin{array}{l}\text { NPE } \\
(\%)\end{array}$ \\
\hline \multicolumn{9}{|l|}{ Forest (75\%) } \\
\hline Uca rapax & 26.6 & 120.8 & 674.6 & 795.4 & 4.53 & 4.9 & 25.4 & 15.2 \\
\hline Uca vocator & 32.5 & 210.7 & 638 & 848.7 & 6.48 & 6 & 19.6 & 24.8 \\
\hline Uca cumulanta & 4.9 & 31.7 & 131 & 162.7 & 6.47 & nd & 26.7 & 19.5 \\
\hline Ucides cordatus & 339.6 & 52.5 & 1256.8 & 1309.3 & 0.16 & nd & 3.7 & 4 \\
\hline Sum & 403.6 & 415.7 & 2700.4 & 3116.1 & & & & \\
\hline \multicolumn{9}{|l|}{ Small creek (17\%) } \\
\hline Uca cumulanta & 14.4 & 143.8 & 405.7 & 549.9 & 9.99 & 10.6 & 28.2 & 26.2 \\
\hline Uca maracoani & 20.1 & 95.4 & 281.7 & 377.1 & 4.74 & nd & 14 & 25.3 \\
\hline Pachygrapsus gracilis & 15.8 & 73.8 & 523.9 & 597.7 & 4.66 & 5.4 & 33.2 & 12.3 \\
\hline Eurytium limosum & 16.4 & 27.1 & 155.1 & 182.2 & 1.65 & nd & 9.5 & 13.5 \\
\hline Thais coronata & 3 & 0.2 & 19.8 & 20.1 & 0.07 & nd & 6.6 & 0.9 \\
\hline Sum & 69.7 & 340.3 & 1386.2 & 1726.5 & & & & \\
\hline \multicolumn{9}{|l|}{ Large creek ( $8 \%)$} \\
\hline Uca maracoani & 216.4 & 1073.7 & 2971.7 & 4045.4 & 4.96 & 5.3 & 13.8 & 27 \\
\hline Thais coronata & 11.8 & 3.1 & 63.9 & 67 & 0.27 & nd & 5.3 & 4.5 \\
\hline Sum & 228.2 & 1076.8 & 3035.6 & 4112.4 & & & & \\
\hline Total & 332.8 & 455.8 & 2503.8 & 2959.6 & 1.37 & nd & 15.4 & 15.8 \\
\hline
\end{tabular}

\section{DISCUSSION}

\section{Biomass and abundance}

All species in the study area have already been reported for this region (e.g. Gerlach 1958, Coelho 1966, 1971, Fausto Filho 1966, 1967, Coelho \& de Araujo Ramos 1972, Coelho et al. 1973, Crane 1975, Macêdo \& Koening 1987, Abele 1992, Schmidt de Melo 1996) and thus would seem to be common representatives of this area. The observed species zonation seems to be related to shore level and temperature regime (e.g. Warner 1967, Macnae 1968, Frith \& Brunnenmeister 1980, Montague 1980, Jones 1984, Macintosh 1988, Robertson \& Alongi 1992, Frusher et al. 1994, Koch 1999), but sediment grain size and organic content are also considered as important factors determining the distribution of deposit-feeding crabs (Altevogt 1957, Miller 1961, Icely \& Jones 1978, Robertson \& Newell 1982, Jaramillo \& Lunecke 1988, Koch 1999). The ability of the fiddler crab Uca maracoani to tolerate much higher temperatures than all other species (as shown by the respiration measurements of Koch 1999), explains its dominance in the large creek stratum, where surface temperatures of up to $40^{\circ} \mathrm{C}$ regularly occurred.

The total epifaunal biomass of 30 to $40 \mathrm{~g} \mathrm{~m}^{-2}$ (in dry mass for better comparison with the literature data) is at the high end of the range commonly reported from other mangrove ecosystems (1.5 to $30 \mathrm{~g} \mathrm{~m}^{-2}$ ) (e.g. Macintosh 1977, Jones 1984, Lalana Rueda \& Gosselck 1986,
Lee 1989, Alongi \& Sasekumar 1992, Wiedemeyer 1997). Much higher values (up to $1200 \mathrm{~g}$ dry mass $\mathrm{m}^{-2}$, however, were found in low intertidal Costa Rican mangroves. There, most biomass was found attached the roots of mangroves and included all hardparts of molluscs and balanids (Büttner 1997).

According to our calculations and estimates (Wolff et al. 2000), epifaunal species contribute about $75 \%$ to the total faunal biomass in the system (Ucides cordatus $63 \%$, deposit-feeding crabs $12 \%$ ) which points to their important role in the ecosystem, with much of the energy and nutrient fluxes being either directly channeled through or dependent on this faunal group.

\section{Energy budgets}

The low species richness and high dominance of a few species allowed the estimation of somatic production for the whole assemblage by means of direct and

Table 3. Contribution of different feeding guilds to total community biomass $(B)$, production $(P)$ and assimilation $(A)$

\begin{tabular}{|llccc|}
\hline \multirow{2}{*}{ Trophic guild } & Species & \multicolumn{3}{c|}{ Contribution (\%) } \\
& & $B$ & $P$ & $A$ \\
\hline Herbivores & Ucides cordatus & 76.2 & 9 & 33.2 \\
Deposit-feeders & $\begin{array}{l}\text { Uca cumulanta, U. maracoani, } \\
\text { U. rapax, U. vocator, }\end{array}$ & & & \\
& $\begin{array}{l}\text { Pachygrapsus gracilis } \\
\text { Purytium limosum, }\end{array}$ & 22 & 89.5 & 65.5 \\
& $\begin{array}{l}\text { Euais coronata } \\
\text { Thators }\end{array}$ & 1.8 & 1.5 & 1.3 \\
\hline
\end{tabular}


precise methods. Rare species, for which production was estimated by means of an empirical relation, contributed less than $3 \%$ to the total (Koch 1999). Our estimates seem valid, as the population turnover rates calculated from the production calculations and total mortality rates $(Z)$ from the length- converted catch curves differed by only 7 to $15 \%$, and the growth rate variability between individuals was low in the fiddler crabs (Koch 1999). As reproductive output and shed carapaces were not considered, total production can be expected to be a little higher. This is believed to introduce only a minor bias, as many semiterrestrial crabs are known to eat their cast after the molt in order to conserve calcium (Hartnoll 1988).

A sensitivity analysis of the effects of measurement errors on our estimates revealed the following: if growth rate and abundance were to vary by $\pm 10 \%$ (which we consider a possible upper error), the overall effect on the production estimate would be $\pm 21 \%$. The same $( \pm 21 \%)$ would hold good for the change in the respiration estimate if abundance and body mass were changed by $\pm 10 \%$. The fact that experiments were not repeated in both seasons should not have introduced a significant error in our estimates as seasonality in tropical species (growth, reproduction, feeding and thus respiration) is generally but weakly pronounced. Moreover, if respiration differs seasonally, this should mostly be due to temperature variation (which was accounted for in Koch's 1999 study). The specific respiration rates of the species studied also compared well to values reported in the literature (Koch 1999).

Macintosh $(1977,1984)$ estimated that the productivity of several mangrove crabs in southeast Asia ranged from 11 to $459 \mathrm{~kJ} \mathrm{~m}^{-2} \mathrm{yr}^{-1}$, but their average production was much lower than that estimated in the present study. Compared with other intertidal communities (Teal 1962, Warwick \& Price 1975, Hibbert 1976, Cammen et al. 1980, Möller et al. 1985, Asmus 1987, Asmus \& Asmus 1990, Fredette et al. 1990, Arias \& Drake 1994, Edgar et al. 1994, Heck et al. 1995, Asmus et al. 1998) our values (range $=340$ to $1076 \mathrm{~kJ} \mathrm{~m}^{-2} \mathrm{yr}^{-1}$; mean $=611 \mathrm{~kJ} \mathrm{~m}^{-2} \mathrm{y}^{-1}$ ) fit well into the range reported for mud- and sandflats (range $=90$ to $2239 \mathrm{~kJ} \mathrm{~m}^{-2} \mathrm{yr}^{-1}$; mean $=742 \mathrm{~kJ} \mathrm{~m}^{-2} \mathrm{yr}^{-1}$ ), and are higher than those reported for temperate saltmarshes (range $=210$ to $301 \mathrm{~kJ} \mathrm{~m}^{-2} \mathrm{yr}^{-1}$; mean $=256 \mathrm{~kJ} \mathrm{~m}^{-2} \mathrm{yr}^{-1}$ ). Secondary production in seagrass (range $=121$ to $2890 \mathrm{~kJ} \mathrm{~m}^{-2} \mathrm{yr}^{-1}$; mean $=1381 \mathrm{~kJ} \mathrm{~m}^{-2} \mathrm{yr}^{-1}$ ) and mussel beds (range = 3793 to $10713 \mathrm{~kJ} \mathrm{~m}^{-2} \mathrm{yr}^{-1}$; mean $=7755 \mathrm{~kJ} \mathrm{~m}^{-2} \mathrm{yr}^{-1}$ ) however, is much higher on the average, possibly due to higher primary productivity and consequently food supply for secondary producers.

Our results indicate that herbivores dominated in terms of biomass, while detritivores contributed the major part to production and total assimilation. Carni- vores contributed little to total energy flow. Two different life strategies seem related to the dominant feeding modes: (1) a high biomass accumulation, low productivity, slow growth and a long life span in Ucides cordatus, as indicated by the low $P / B$-ratio and growth data from Diele (2000), versus (2) lower biomass, high productivities, fast growth and short life spans in the fiddler crabs. The net production efficiencies (NPE) are a further indication thereof: while all deposit feeders (the fiddler crabs and Pachygrapsus gracilis) had NPE values from 12 to $26 \%$, the large mangrove crab had a much lower value of only $4 \%$, using most of its assimilated energy for maintenance and metabolism. These differing strategies possibly evolved as adaptations related to the food consumed by the 2 groups.

Food supply for Ucides cordatus is high in the study area (Mehlig pers. comm.), but high $\mathrm{C} / \mathrm{N}$ ratios, tannin and lignin concentrations render mangrove leaves to a food that is hard to digest and of low nutritional value, although ageing improves their nutrient composition and digestibility (e.g. Giddins et al. 1986, Micheli et al. 1991, Emmerson \& McGwynne 1992, Kwok \& Lee 1995). Food uptake per unit time can be restricted by the long gut-passage times required to break up this food type (Wolcott 1988). The low digestibility and 'poor' food quality of leaf litter thus favors a slow metabolism and low overall energy expenditures (and larger size). Respiration per unit biomass $(R / B)$ of $U$. Cordatus was consequently 3.5 to 8 times lower than that of the deposit-feeding crabs (Table 2), resulting in comparably lower metabolic costs for the former.

The main food source for the fiddler crabs are bacteria growing on plant detritus (Montague 1980, Genoni 1985, Dye \& Lasiak 1986, 1987). Bacterial production is high in mangrove soils, but the resource is patchily distributed in space and time (Alongi 1988, Robertson et al. 1992). It can thus be argued that the high productivities and the fast metabolism of the deposit-feeding crabs are adaptations to the highly productive but variable and unpredictable food resource. Gut-passage time is very short (only 2 to 3 h: Koch 1999), allowing large quantities of organic matter to be processed per unit time, and assimilating only the microbial biomass and some microalgae and protozoans (Altevogt 1957, Miller 1961, Crane 1975, Montague 1980, Robertson \& Newell 1982, Dye \& Lasiak 1986, 1987). It is very likely that the different production figures of the deposit feeders in the 3 strata are caused by differences in food supply. This, however, cannot be demonstrated as yet, since no estimates of bacterial production and turnover of organic matter are available for the study area.

The predatory guild of the crab Eurytium limosum and the gastropod Thais coronata does not contribute much to total production and respiration $(<2 \%)$. However, the crab is an important predator of other crabs 
and also of molluscs in the small creek stratum (Koch 1999), and the snail is probably the main predator of teredinid shipworms in the area (Koch pers. obs.). Food consumption of E. limosum calculated for the whole area equals about $20 \%$ of the total production estimated for the Furo do Meio (Koch 1999). No consumption data are available for $T$. coronata, but if we use the estimate of Koch \& Wolff (1996) for the closely related T. kiosquiformis (approx. $1 \%$ fresh mass $\mathrm{d}^{-1}$ ), the snail would also be expected to consume 40 to $50 \mathrm{~kJ} \mathrm{~m}^{-2} \mathrm{yr}^{-1}$ of wood-boring molluscs. It is therefore likely that these species are important regulators of their prey populations.

The much lower productivity of the gastropod in the small creek probably resulted from the lower food supply here, as described for the related species Nucella lapillus (Hughes 1972). Biomass of teredinids appeared to be lower in the mangrove trunks in the small creek, which were much older than those in the large creek and already showed strong signs of decay (Koch pers. obs.).

The fate of biomass production is quite different in the dominant trophic guilds. Adult Ucides cordatus have few predators in low abundance (e.g. crab racoons, capucin monkeys, yellow-headed caracaras and crab hawks) which do not exert strong predation pressure upon the population (Wolff et al. 2000). The most important source of 'predation' on this species is the commercial harvest, with a catch of approx. 1500 tons $\mathrm{yr}^{-1}$ from an area smaller than $100 \mathrm{~km}^{2}$. Deposit-feeders, on the other hand, are heavily preyed upon by many species, as shown in the trophic model of Wolff et al. (2000). According to their model estimates, predation on fiddler crabs is almost 15 times higher than on $U$. cordatus and the former are the most important food source for many species in the mangrove ecosystem.

It appears that mangroves, crabs and bacteria are connected in the form of a positive feedback loop sensu Ulanowicz (1997), whereby an increase in the activity of any participant will tend to increase the activity of all others as well. The upper boundaries to growth of these structures are set by (e.g.) resource availability, competition or predation. A simple model (Fig. 4) illustrates this loop for the system under study. Pathways of energy flow and their magnitude are included, where available. U. cordatus benefits from the amount of primary production, but assimilates only a fraction of the available energy (about 10\%), while the remainder fuels the microbial loop in the detritus compartment, enhancing the food supply of the deposit-feeding crabs. The trees benefit from the activity of crabs and bacteria as (1) nutrients are retained in the system by $U$. cordatus, (2) nutrient remineralization is enhanced through shredding of the leaf material and the high grazing pressure exerted on microbes, and (3) the soil is aerated by the burrowing and feeding activities of the crabs, thus preventing or diminishing the formation of phytotoxins such as $\mathrm{H}_{2} \mathrm{~S}$ in the sediment.

Possibly as a result of the positive feedback mechanisms and tight coupling between mangroves, crabs, and bacteria, total mangrove primary production (MPP) in the Caeté estuary equals $1350 \mathrm{~g}$ dry mass $\mathrm{m}^{-2}$ $\mathrm{yr}^{-1}$ (approx. $21000 \mathrm{~kJ} \mathrm{~m}^{-2} \mathrm{yr}^{-1}$ ), lying at the high end of the values published elsewhere (Mehlig pers. comm.). Almost $15 \%$ of MPP in the Caeté system is assimilated by the epibenthic assemblage. In other mangrove ecosystems, the fauna assimilates a much lower percentage. Golley et al. (1962) estimated total faunal respiration in a red mangrove stand in Florida to equal about $3.5 \%$ MPP (i.e. $4.6 \%$ assimilated assuming a $P / R$ ratio of 0.3 ). Mangrove fauna consumed about $6.2 \%$ of MPP in a Northeast Brazilian mangrove (Wiedemeyer 1997) (i.e. $2.5 \%$ of MPP assimilated assuming an assimilation efficiency of $40 \%$ ). Teal (1962) reported that about $4.6 \%$ of MPP were assimilated by

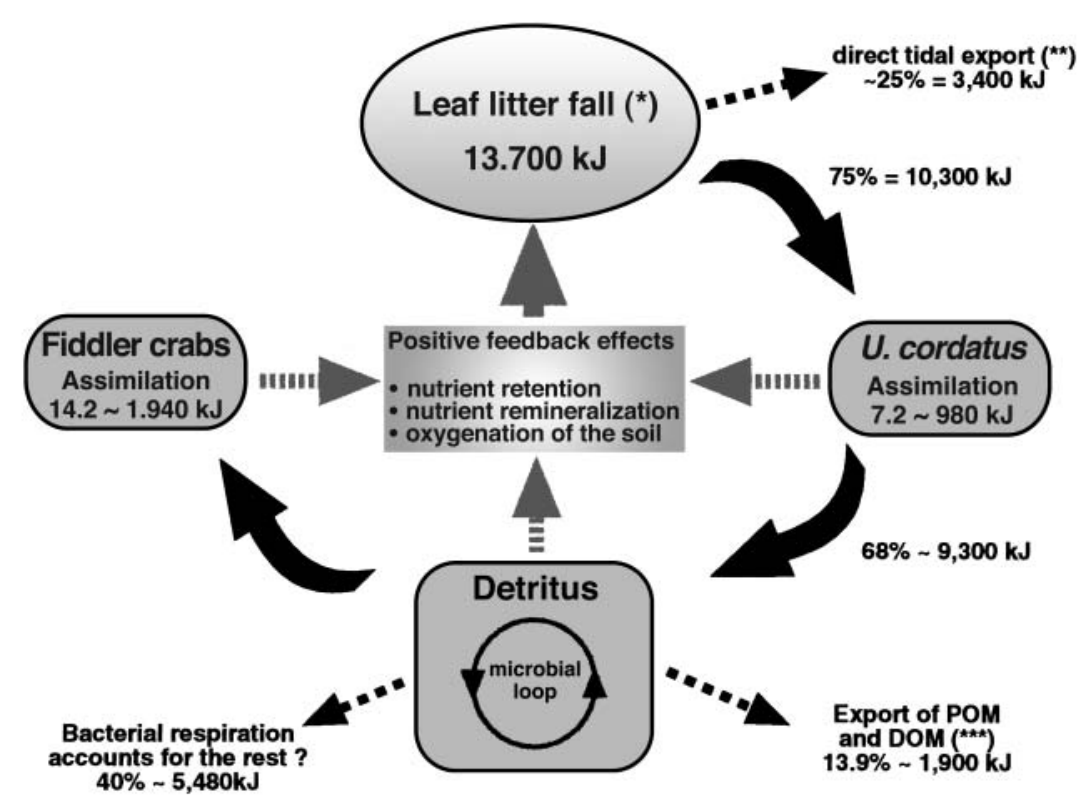

Fig. 4. Quantified model of the main pathways of energy and magnitude in the Caeté mangrove forest. The positive feedback effects suggested in the text are included as well. Data were taken from Koch (1999), and from Mehlig (pers. comm.:*), Schories (pers. comm.: $\left.{ }^{* *}\right)$ and Dittmar $\left(1999:^{* * *}\right)$. Microbial respiration is not known; it is assumed to balance the energy budget. Note that only leaf litter fall is included in the model 
saltmarsh macrofauna and Cammen et al. (1980) found that $3.6 \%$ of MPP were assimilated by 2 fiddler crabs and a littorinid snail in a salt marsh. The higher assimilation efficiency in the Caeté mangroves can be explained in part by the low inundation frequencies, whereby leaves remain for up to $10 \mathrm{~d}$ on the forest floor before they are exported (thus resulting in a higher local food supply). However, the described feedback loop appears to be the main reason for the almost 3-fold higher assimilation efficiency in the system under study.

The function and performance of a feedback loop can be disturbed by reducing or eliminating any of its components. The high fishing pressure upon the large mangrove crab is apparently the most imminent danger apart from large scale logging of the mangroves themselves. According to our model, a highly reduced biomass of Ucides cordatus would alter the energy flow patterns in the system. Most leaf litter would remain unconsumed on the forest floor, being exported with the next spring tide. The decreased amount of organic matter in the forest would result in reduced bacterial production and, due to food shortage, in lower production of depositfeeding crabs. Mangrove primary production would also eventually decrease as a result of the decline in nutrient availability and less favourable sediment conditions.

The coastal food web, however, would benefit from the increased input of mangrove detritus, resulting in a higher aquatic secondary productivity. The 'ano do camarão' (year of the shrimp) is an indication thereof. Every 5 to $10 \mathrm{yr}$, the caterpillars of a moth species (Hyblea puera complex, det. W. Speidel) consume a large part of the leaf mass of Avicennia germinans on the peninsula within a few weeks. The forest floor is then littered with feces and leaf particles, which are exported with the next spring tide into the estuary. According to local fishermen, shrimp catches in those years are much higher than in 'normal' years (D. Pinho de Araujo pers. comm.), possibly as a result of the increased amount of organic matter available to the aquatic fauna.

Acknowledgements. We would like to thank all our Brazilian and German colleagues and friends for their cooperation and help. Many, many thanks to Susanne Knieriem for her help, love and friendship. Special thanks to Ulf Mehlig, Karen Diele, Olaf Gundermann and Verena Rademaker Wolff for their help, fruitful discussions and for sharing some of the long hours in the mud. This study was undertaken within the MADAM project, a Brazilian-German cooperation in the field of scientific research and technological development financed by the German Ministry of Education, Science, Research and Technology (BMBF), Project number 03F0154A. This is MADAM contribution No. 31.

\section{LITERATURE CITED}

Abele LG (1992) A review of the grapsid crab genus Sesarma (Crustacea: Decapoda: Grapsidae) in America, with the description of a new genus. Smithson Contrib Zool 527

Allen KR (1971) Relation between production and biomass. J Fish Res Board Can 28:1573-1581

Alongi DM (1988) Bacterial productivity and microbial biomass in tropical mangrove sediments. Microb Ecol 15: 1573-1581

Alongi DM, Sasekumar A (1992) Benthic communities. In: Robertson AI, Alongi DM (eds) Tropical mangrove ecosystems. American Geophysical Union, Washington DC, p $137-171$

Altevogt R (1957) Untersuchungen zur Biologie, Ökologie und Physiologie indischer Winkerkrabben. Z Morphol Ökol Tiere 46:1-110

Arias AM, Drake P (1994) Structure and production of the benthic macroinvertebrate community in a shallow lagoon in the Bay of Cádiz. Mar Ecol Prog Ser 115:151-167

Asmus HA (1987) Secondary production of an intertidal mussel bed community related to its storage and turnover compartments. Mar Ecol Prog Ser 39:251-266

Asmus HA, Asmus RM (1990) Trophic relationships in tidal flat areas: to what extent are tidal flats dependent on imported food? Neth J Sea Res 27:93-99

Asmus HA, Lackschewitz D, Asmus RM, Scheiffarth G, Nehls G, Herrmann JP (1998) Carbon flow in the food web of tidal flats in the Sylt-Rømø Wadden Sea. In: Gätje C, Reise K (eds) Ökosystem Wattenmeer-Austausch-, Transport-, und Stoffumwandlungsprozesse. Springer-Verlag, Berlin, p 393-420

Benke AC (1979) A modification of the Hynes method for estimating secondary production with particular significance for multivoltine species. Limnol Oceanogr 24: 168-171

Büttner H (1997) Zur Ökologie der Wurzelgemeinschaft der roten Mangrove Rhizophora mangle L. an der Pazifikküste Costa Ricas. PhD thesis, University of Bremen

Caddy JF, Sharp GD (1986) An ecological framework for marine fisheries investigations. FAO Fish Tech Pap 283

Cammen LM, Seneca ED, Stroud LM (1980) Energy flow through the fiddler crabs Uca pugnax and Uca minax and the marsh periwinkle Littorina irrorata in a North Carolina salt marsh. Am Midl Nat 103:238-250

Coelho PA (1966) Os crustáceos decápodos de alguns manguezais pernambucanos. Trab Oceanogr Univ Fed Pe 7/8: 71-90

Coelho PA (1971) A distribuição dos crustáceos reptantes do Norte de Brasil. Trab Oceanogr Univ Fed Pe 9/11:223-238

Coelho PA, Araújo Ramos M (1972) A constituição e a distribuição da fauna de decápodos do litoral de América do Sul entre as latitudes de $5^{\circ} \mathrm{N}$ e $39^{\circ} \mathrm{S}$. Trab Oceanogr Univ Fed Pe 13:133-236

Coelho PA, Koening ML, Araújo Ramos M (1973) A macrofauna béntica dos estuarios de Pernambuco e da Paraiba. Acta IV Congr Latin Zool 2:497-528

Crane J (1975) Fiddler crabs of the world. Ocypodidae: genus Uca. Princeton University Press, Princeton

Crisp DJ (1984) Energy flow measurements. In: Holme NA, MacIntyre AD (eds) Methods for the study of marine benthos. IBP handbook No. 16, Blackwell Science, Oxford, p 285-372

Diele K (2000) Life history and population structure of the exploited mangrove crab Ucides cordatus cordatus (Linnaeus 1763) (Crustacea, Decapoda) in the Caeté Estuary, North Brazil. PhD thesis, University of Bremen 
Dittmar T (1999) Outwelling of organic matter and nutrients from a mangrove in North Brazil: evidence from organic tracers and flux measurements. $\mathrm{PhD}$ thesis, University of Bremen

Dye AH, Lasiak TA (1986) Microbenthos, meiobenthos and fiddler crabs: trophic interactions in a tropical mangrove sediment. Mar Ecol Prog Ser 32:259-264

Dye AH, Lasiak TA (1987) Assimilation efficiencies of fiddler crabs and deposit-feeding gastropods from tropical mangrove sediment. Comp Biochem Physiol A 87:341-344

Edgar GJ, Shaw C, Watson GF, Hammond LS (1994) Comparisons of species richness, size-structre and production in vegetated and unvegetated habitats in Western Port, Victoria. J Exp Mar Biol Ecol 176:201-226

Emmerson WD, McGwynne LE (1992) Feeding and assimilation of mangrove leaves by the crab Sesarma meinerti de Man in relation to leaf litter production in Mgazana, a warm-temperate southern African mangrove swamp. J Exp Mar Biol Ecol 57:41-53

Fausto Filho J (1966) Primeira contribuição ao inventario dos crustáceos decápodos marinhos do nordeste brasileiro. Arq Estac Biol Mar Univ Fed Ceará 6:31-37

Fausto Filho J (1967) Segunda contribuição ao inventario dos crustáceos decápodos marinhos do nordeste brasileiro. Arq Estac Biol Mar Univ Fed Ceará 7:11-14

Fredette TJ, Diaz RT, van Montfrans, J Orth RJ (1990) Secondary productivity within a sea grass bed (Zostera marina and Ruppia maritima). Estuaries 13:431-440

Frith DW, Brunnenmeister S (1980) Ecological and population studies of fiddler crabs (Ocypodidae, genus Uca) on a mangrove shore at Phuket Island, western peninsula Thailand. Crustaceana 39:157-184

Frusher SD, Giddins RL, Smith TJ III (1994) Distribution and abundance of grapsid crabs in a mangrove estuary: effects of sediment characteristics, salinity tolerances and osmoregulatory ability. Estuaries 17:647-654

Genoni GP (1985) Food limitation in salt marsh fiddler crabs Uca rapax (Smith) (Decapoda: Ocypodidae). J Exp Mar Biol Ecol 87:97-110

Gerlach SA (1958) Die Mangrovenregion tropischer Küsten als Lebensraum. Z Morphol Ökol Tiere 46:636-730

Giddins RL, Lucas JS, Neilson MJ, Richards GN (1986) Feeding ecology of the mangrove crab Neosarmatium smithi (Crustacea: Decapoda: Brachyura). Mar Ecol Prog Ser 33:147-155

Glasen M, Furtade L, Nascimento I, Santana G (1997) Economy, ecosystem and society: mangroves and people in the Caeté Bay, North Brazil. Annual conference, Development Studies Association, University of East Anglia, Norwich, September 1997

Golley F, Odum H, Wilson RF (1962) The structure and metabolism of a Puerto-Rican red mangrove forest in May. Ecology 43:9-19

Hamilton AL (1969) On estimating annual production. Limnol Oceanogr 14:771-782

Hartnoll RG (1988) Growth and mortality. In: Burgren WW, McMahon BR (eds) Biology of the land crabs. Chapter 6. Cambridge University Press, Cambridge, UK, p 186-210

Heck KL Jr, Able KW, Roman CT, Fahay MP (1995) Composition, abundance, biomass and production of macrofauna in a New England estuary: comparisons among eelgrass meadows and other nursery habitats. Estuaries 18:379-389

Hibbert CJ (1976) Biomass and production of a bivalve community on an intertidal mudflat. J Exp Mar Biol Ecol 25: 249-261

Hughes RN (1972) Annual production of two Nova Scotian populations of Nucella lapillus (L.). Oecologia (Berl) 8: $356-370$
Hynes HB, Coleman MJ (1968) A simple method for assessing the annual production of stream benthos. Limnol Oceanogr 13:569-575

Icely JD, Jones DA (1978) Factors affecting the distribution of the genus Uca (Crustacea: Ocypodidae) on an East African shore. Estuar Coast Shelf Sci 6:315-325

INMET (Institut Nacional de Metereologia) (1992) Normais climatológicas (1961-1990). Tech Rep Instituto Nacional de Metereologia, Brasilia DF, Brasil

Ivlev VS (1966) The biological productivity of waters. J Fish Res Board Can 23:1327-1359. (Transl by W. E. Ricker. Originally published in 1945 in Usp Sovrem Biol 19: [in Russian])

Jaramillo E, Lunecke K (1988) The role of sediments in the distribution of Uca pugilator and Uca pugnax in a salt marsh of Cape Cod. Meeresforschung 32:46-52

Jones D (1984) Crabs of the mangal ecosystem. In: Por F, Dor I (eds) Hydrobiology of the mangal. Junk Publishers, The Hague, p 89-109

Koch V (1995) Zur Populationsbiologie und ökologischen Rolle der Mangrovenschnecke Thais kiosquiformis im Golf von Nicoya, Costa Rica. MSc thesis, University of Bremen

Koch V (1999) Epibenthic production and energy flow in the Caeté mangrove estuary, North Brazil. PhD thesis University of Bremen

Koch V, Wolff M (1996) The mangrove snail Thais kiosquiformis Duclos: a case of life history adaptation to an extreme environment. J Shellfish Res 8:421-432

Koch V, Wolff M, Grönemeier V, Sorgenicht E (1998) A device for accurate and rapid size measurements of molluscs. J Shellfish Res 17:1259-1261

Kwok PW, Lee SY (1995) The growth performance of two mangrove crabs, Chiromanthes bidens and Parasesarma plicata under different leaf litter diets. Hydrobiologia 295: 141-148

Lalana Rueda R, Gosselck F (1986) Investigations of the benthos of mangrove coastal lagoons in Southern Cuba. Int Rev Gesamten Hydrobiol 71:779-794

Lee SY (1989) The importance of sesarmine crabs Chiromanthes spp. and inundation frequency on mangrove (Kandelia candel [L.] Druce) leaf litter turnover in a Hong Kong tidal shrimp pond. J Exp Mar Biol Ecol 131:23-43

Macêdo SJ, Koening ML (1987) Áreas estuarinas do estado de Pernambuco (Bibliografia comentada). Tech Rep Univ Fed Pernambuco, Recife, Brasil

Macintosh DJ (1977) Quantitative sampling and production estimates of fiddler crabs in a Malaysian mangrove. Mar Res Indones 18:59

Macintosh DJ (1984) Ecology and productivity of Malaysian mangrove crab populations (Decapoda: Brachyura). In: Ong JE, Gong WK (eds) Proceedings of the workshop on productivity of the Mangrove ecosystem: management implications, Universite Sains Malaysia, Penang, p 354-377

Macintosh DJ (1988) The ecology and physiology of decapods of mangrove swamps. In: Fincham A, Rainbow PS (eds) Aspects of decapod crustacean biology. Symp Zool Soc London, No. 59, p 315-341

Macnae W (1968) A general account of the fauna and flora of mangrove swamps and forests in the Indo-West-Pacific region. Adv Mar Biol 6:73-170

McDonald J (1982) Divergent life history patterns in the cooccurring intertidal crabs Panopeus herbsti and Eurypanopeus depressus (Crustacea: Brachyura: Xanthidae). Mar Ecol Prog Ser 8:173-180

Micheli F, Gherardi F, Vannini M (1991) Feeding and burrowing ecology of two East African mangrove crabs. Mar Biol 111:247-254 
Miller DC (1961) The feeding mechanisms of fiddler crabs, with ecological considerations of feeding adaptations. Zoology (Jena) 46(8):89-101

Möller P, Phil L, Rosenberg R (1985) Benthic faunal energy flow and biological interaction in some shallow marine soft bottom habitats. Mar Ecol Prog Ser 27:109-121

Montague CL (1980) A natural history of temperate Western Atlantic fiddler crabs (genus $U_{c a}$ ) with reference to their impact on the salt marsh. Contrib Mar Sci 23:25-55

Odum WE, Heald EJ (1972) Trophic analysis of an estuarine mangrove community. Bull Mar Sci 22:671-738

Robertson AI (1986) Leaf-burying crabs: their influence on energy flow and export from mixed mangrove forests (Rhizophora spp.) in northeastern Australia. J Exp Mar Biol Ecol 102:237-248

Robertson AI (1991) Plant-animal interactions and the structure and function of mangrove forest ecosystems. Aust $\mathrm{J}$ Ecol 16:433-443

Robertson AI, Alongi DM (eds) (1992) Tropical mangrove ecosystems. American Geophysical Union, Washington, DC

Robertson AI, Daniel PA (1989) The influence of crabs on leaf litter processing in a high intertidal mangrove forest in tropical Australia. Oecologia 78:191-198

Robertson JR, Newell SY (1982) A study of particle ingestion by three fiddler crab species foraging on sandy sediments. J Exp Mar Biol Ecol 65:11-17

Robertson AI, Alongi DM, Boto KG (1992) Food chains and carbon fluxes. In: Robertson AI, Alongi DM (eds) Tropical mangrove ecosystems. Chapter 10. American Geophysical Union, Washington, DC

Schmidt de Melo GA (1996) Manual de identificação dos

Editorial responsibility: Otto Kinne (Editor),

Oldendorf/Luhe, Germany
Brachyura (caranguejos e sirís) do litoral brasileiro. Plêiade/ FABESP, São Paulo

Spalding M, Blasco F, Field CD (eds) (1997) World mangrove atlas. International Society for Mangrove Ecosystems, Okinawa

Teal JM (1962) Energy flow in the salt marsh system of Georgia. Ecology 43:614-624

Thüllen N (1997) Analyse der Struktur eines Mangrovenwaldgebietes bei Bragança, Nordbrasilien und Untersuchungen ihr zugrundeliegender abiotischer und biotischer Faktoren. MSc thesis, University of Bremen

Ulanowicz RE (1997) Ecology, the ascendent perspective. Complexity in Ecological Systems. Columbia University Press, New York

Warner GF (1967) The life history of the mangrove tree crab Aratus pisoni. J Zool (Lond) 153:321-335

Warwick RM, Price R (1975) Macrofauna production in an estuarine mudflat. J Mar Biol Assoc UK 55:1-18

Wiedemeyer W (1997) Analysis of a benthic food web of a mangrove ecosystem at northeastern Brazil. PhD thesis, University of Kiel

Wolcott TG (1988) Ecology. In: Burgren WW, McMahon BR (eds) Biology of the land crabs. Chapter 3. Cambridge University Press, Cambridge, UK, p 55-96

Wolff M, Koch V, Chavarria JB, Vargas JA (1998) A trophic flow model of the Golfo de Nicoya, Costa Rica. Rev Biol Trop 46(Suppl 6):63-79

Wolff M, Koch V, Isaac V (2000) A trophic flow model of the Caeté mangrove estuary, North Brazil, with considerations of the sustainable use of its resources. Estuar Coast Shelf Sci 50:789-803

Submitted: October 16, 2000; Accepted: April 12, 2001 Proofs received from author(s): February 12, 2002 